\title{
RESÍDUOS SÓLIDOS NA ESCOLA: uma experiência vivenciada no curimataú paraibano, Brasil
}

\section{SOLID WASTE AT SCHOOL: an experience experienced in curimataú paraibano, Brazil}

\section{RESIDUOS SÓLIDOS EN LA ESCUELA: una experiencia experimentada en curimataú paraibano, Brasil}

\author{
Edvan Silva CASADO ${ }^{1}$ \\ Ronny Diógenes de MENEZES ${ }^{2}$
}

1. Licenciada em Ciências Biológicas. Especialista em Formação do Educador. Mestre em Ciências da Educação. E-mail: edvancasado@ bol.com.br

2. Graduado em Letras/Português. Professor da Universidade Federal do Rio Grande do Norte. Programa de Pós-Graduação em Linguagem e Ensino - Universidade Federal de Campina Grande-PB. E-mail: ronny.diogenes@gmail.com.

RESUMO: Objetivou-se com esse estudo analisar a percepção da comunidade escolar quanto aos resíduos sólidos gerados por uma escola pública na cidade de Barra de Santa Rosa-PB. Tratou-se de uma pesquisa exploratória-descritiva de caráter qualitativo, com uso de aplicação dos questionários junto à comunidade escolar. Participaram da pesquisa 40 alunos de duas turmas do $8^{\circ}$ e duas do $9^{\circ}$ ano; 3 gestores, 12 funcionários e 26 professores. Desta forma, verificou-se que os resíduos recicláveis gerados na escola são misturados e descartados como resíduos comuns, porém, os papéis e os plásticos poderiam ser reaproveitados e reciclados, mas a escola não possui um Programa de separação de resíduos, isso talvez se justifique devido à inexistência de uma coleta seletiva municipal. Foi possível notar a ausência de coletores identificados, conforme os tipos de resíduos produzidos, distribuídos no espaço escolar, à existência apenas de um coletor em cada sala, e que a maioria dos alunos não utiliza os coletores para depositar os resíduos e joga-os no chão da sala de aula. Não ocorre aproveitamento dos materiais orgânicos, como restos de comida e cascas de verduras que são também misturadas e descartadas como resíduos comuns, enquanto poderiam ser reutilizadas para compostagem. Concluindo que a comunidade escolar necessita ser sensibilizada para entender que especialmente a escola tem que contribuir para construção de um mundo melhor, mais sustentável.

Palavras-chave: Educação Ambiental. Descarte de Resíduos. Gerenciamento de Resíduos.

\begin{abstract}
The objective of this study was to analyze the perception of the school community regarding the solid waste generated by a public school in the city of Barra de Santa Rosa-PB. It was a qualitative exploratory-descriptive research, using questionnaires in the school community. Forty students from two classes from the 8th and two from the 9th grade participated in the research; 3 managers, 12 employees and 26 teachers. Thus, it was found that the recyclable waste generated at the school is mixed and disposed of as ordinary waste, however paper and plastics could be reused and recycled, but the school does not have a waste separation program, this may be justified. due to the lack of a municipal selective collection. It was possible to notice the absence of identified collectors, according to the types of waste produced, distributed in the school space, the existence of only one collector in each room, and that most students do not use the collectors to deposit the waste and throw it in the classroom floor. There is no use of organic materials, such as food scraps and vegetable peels, which are also mixed and discarded as common waste, while they could be reused for composting. In conclusion, the school community needs to be sensitized to understand that especially the school has to contribute to building a better, more sustainable world.
\end{abstract}

Keywords: Environmental education. Waste Disposal. Waste management.
RESUMEN: El objetivo de este estudio fue analizar la percepción de la comunidad escolar sobre los residuos sólidos generados por una escuela pública en la ciudad de Barra de Santa Rosa-PB. Fue una investigación cualitativa exploratoriadescriptiva, utilizando cuestionarios en la comunidad escolar. En la investigación participaron cuarenta estudiantes de dos clases del octavo y dos del noveno grado; 3 gerentes, 12 empleados y 26 profesores. Así, se encontró que los residuos reciclables que se generan en la escuela se mezclan y eliminan como residuos ordinarios, sin embargo, el papel y los plásticos se podrían reutilizar y reciclar, pero la escuela no cuenta con un programa de separación de residuos, esto puede estar justificado. por falta de recogida selectiva municipal. Se pudo notar la ausencia de recolectores identificados, de acuerdo a los tipos de desechos producidos, distribuidos en el espacio escolar, la existencia de un solo recolector en cada salón, y que la mayoría de los estudiantes no utilizan los recolectores para depositar los desechos y tirarlos al jardín. piso del aula. No se utilizan materiales orgánicos, como restos de comida y cáscaras de vegetales que también se mezclan y desechan como desechos comunes, mientras que podrían reutilizarse para compostaje. En conclusión, es necesario sensibilizar a la comunidad escolar para que comprenda que, especialmente, la escuela debe contribuir a la construcción de un mundo mejor y más sostenible.

Palabras-clave: Educación ambiental. Deposito de basura. Gestión de resíduos. 


\section{INTRODUÇÃO}

A preocupação com o meio ambiente para os seres humanos não é recente, remonta desde os primórdios, em função da necessidade de sobrevivência e de transmitir aos mais jovens os saberes para a vida no lugar onde vivem. Assim sendo, a existência de uma preocupação com relação ao modo de vida e o futuro do meio ambiente se fazia presente desde o homem primitivo, seres caçadores e coletores de recursos naturais e também em uma época posterior com a organização dos primeiros grupos que fizeram da agricultura seu modo de subsistência (FREITAS, 2018).

Assim, presenciamos diariamente notícias que tem como foco situações de degradação ambiental e dispomos de inúmeros estudos sobre questões ambientais, que revelam a urgência da tomada de decisão frente ao estilo de vida na atualidade.

Araújo e Magalhães (2010) afirmam que:

(...) nos tempos mais remotos, os seres humanos usufruíam do mundo para proveito próprio, a partir de determinado momento começou a tentar conhecê-lo, o que consequentemente levou à sua transformação. Inicialmente, o Homem procurou apenas melhorar a sua estratégia de vida, mas, posteriormente, concentrou-se na melhoria do seu bem-estar e num terceiro momento, começou a alterar drasticamente "o curso natural das coisas" (ARAÚJO; MAGALHÃES, 2010, p. 304).

Portanto, as discussões sobre o futuro do planeta, lançamentos de campanhas de sensibilização e conscientização não está surtindo concretamente efeito na sociedade, que continua com os mesmos procedimentos errôneos de antigamente de quando se imaginava não existir relação sociedade x natureza, tudo isso motivado pelas grandes empresas que só pensam no lucro e fazem de tudo para que à sociedade continue alienada ao consumismo, pois assim mais benefícios terão. Faz-se necessário buscar "soluções" para os problemas ambientais, os diversos setores da sociedade precisam correr contra o tempo para “corrigir os excessos que têm caracterizado a sua ação sobre o meio ambiente". (ARAUJO; MAGALHÃES, 2010).

Estamos indo na contramão de Gadotti (2010), quando diz que é preciso ser tomada medidas em diversas áreas, inserindo conceitos e ações, objetivando uma "Economia Verde", o "Desenvolvimento Sustentável" e a "Sustentabilidade"; além de políticas públicas e a proposta de novos estilos de vida para a sociedade, com uma maior consciência ecológica.

Neste ínterim, entra a Escola, pois somente com indivíduos mais preparados e conscientes e a importância de uma Educação voltada para o ambiente tem a condição de colaborar significativamente para uma sociedade mais justa e humanizada. Pois, a inserção de profissionais desde a Educação Infantil preparados e engajados no compromisso de formar cidadãos preocupados com o ambiente em que vivem, pode ser que consigamos colaborar com o planeta. Portanto, "pensar globalmente e agir localmente" no âmbito da Educação desde os anos iniciais do ensino básico até o ensino superior é a forma que podemos 
permanecer mais tempo ocupando o Planeta Terra como seres humanos que somos em convivência com as demais espécies que dividem esse espaço terrestre e marítimo conosco.

Assim sendo, analisar a produção e gerenciamento dos resíduos sólidos é de extrema importância para o desenvolvimento da Educação Ambiental (EA) nas instituições de educação básica para auxiliar no enfrentamento dos problemas socioambientais causados pelos resíduos. Com isso, a análise da geração desses resíduos, contribuirá para a formação de indivíduos conscientes de sua responsabilidade para com o meio ambiente e a sociedade.

Conforme Loureiro (2003):

\begin{abstract}
Para se chegar à compreensão dos problemas nacionais e internacionais, deve-se partir do cotidiano, possibilitando a construção de um sentido coerente no discurso ambiental para os educandos (do concreto para o abstrato). É preciso construir um senso de pertencimento a uma comunidade, a uma localidade definida, ser um cidadão local para sê-lo no nível planetário (LOUREIRO, 2003, p. 53).
\end{abstract}

Com isso, partimos da hipótese que a maior parte dos professores das instituições de Educação básica não possui formação adequada na área da Educação Ambiental para subsidiar as suas ações e em consequência disso, os alunos não recebem formação escolar em Educação Ambiental sobre o tema resíduos sólidos. No entanto, acredita-se que muitos professores apesar da formação precária realizam trabalhos de Educação Ambiental, conforme apontam os estudos de Oliveira e Giordano (2018) e Silva (2017). Entretanto, é comum que os professores limitem as atividades realizadas com as crianças a segregação dos Resíduos.

A destinação adequada dos resíduos sólidos produzidos na escola, além de favorecer a tomada de consciência e a formação de indivíduos responsáveis e atuantes na construção de uma sociedade sustentável, contribuirá para o aumento da vida útil do aterro sanitário local quando instalado, caso essa temática for trabalhada dentro de uma perspectiva de educação ambiental contínua e efetiva.

Dessa forma, o objetivo geral desta pesquisa foi analisar a percepção da comunidade escolar quanto aos resíduos sólidos gerados por uma escola pública na cidade de Barra de Santa Rosa-PB.

\title{
METODOLOGIA
}

De acordo com Gil (2002) uma pesquisa do tipo descritiva e exploratória pode ser descrita como:

[...] um tipo de pesquisa com base empírica que é concebida e realizada em estreita associação com uma ação ou com a resolução de um problema coletivo e no qual os pesquisadores e participantes representativos da situação ou do problema estão envolvidos de modo cooperativo ou participativo. (GIL, 2002, p. 55).

Quanto à abordagem metodológica, o estudo é quanti-qualitativo, uma vez que, o objetivo desse estudo foi fazer a caracterização quantitativa e qualitativa dos resíduos sólidos em uma escola, ao mesmo 
tempo em que analisa as percepções e comportamentos dos gestores, professores e aluno da escola no que se refere à questão dos resíduos sólidos. Foram utilizados como instrumento de coleta de dados a aplicação de questionários e a pesagem dos resíduos produzidos em uma semana letiva, na Instituição.

A pesquisa foi realizada por meio de amostragem, cujo critério de inclusão foi à adequação dos alunos no contexto série e faixa etária, sendo o estudo realizado apenas no turno matutino. Dentro desta perspectiva foram escolhidas quatro turmas dos anos finais do Ensino Fundamental para realizar o estudo de caracterização dos resíduos sólidos.

Foram escolhidas para participar da pesquisa duas turmas do $8^{\circ}$ e duas do $9^{\circ}$ ano, devido ao grupo ter demonstrado interesse na pesquisa durante a fase de caracterização dos resíduos sólidos na escola. Além do que, os alunos das séries finais do Ensino Fundamental teoricamente possuem mais conhecimento e maturidade para responderem ao questionário.

O estudo foi realizado em uma escola de Ensino Fundamental da Rede Pública Municipal da cidade de Barra de Santa Rosa-PB. A critério dos pesquisadores e de forma aleatória foi atribuído os códigos G1, G2 e G3 para os gestores; F1, F2, .., F11, F12, para os funcionários; P1, P2, ..., P25, P26, para os Professores participantes da pesquisa e os códigos A81, A82..., A89, A810 para os alunos dos $8^{\circ}$ anos e A91, A92..., A99, A910 para os alunos dos $9^{\circ}$ anos participantes da pesquisa, dessa forma, garantindo o direito ao anonimato, e assim, poder ser identificado todas as falas de todos os pesquisados nos resultados.

Não houve interferência nos ambientes da escola quanto à instalação de coletores identificados, para que os alunos, gestores, professores e funcionários fizessem os descartes aleatoriamente.

No pátio da escola (ambiente comum a todos) os pesquisadores colocoram três coletores (Figura 1), sendo um para resíduos recicláveis, outro descarte de resíduos comuns e um para possíveis resíduos orgânicos, uma vez que estes ambientes possuem um fluxo maior de pessoas, quando comparado às salas de aulas, a sala da gestora e a sala dos professores.

Figura 1. Instalação dos coletores para resíduos comuns, recicláveis e orgânicos por parte da pesquisadora no pátio interno da Escola pesquisada. 2019

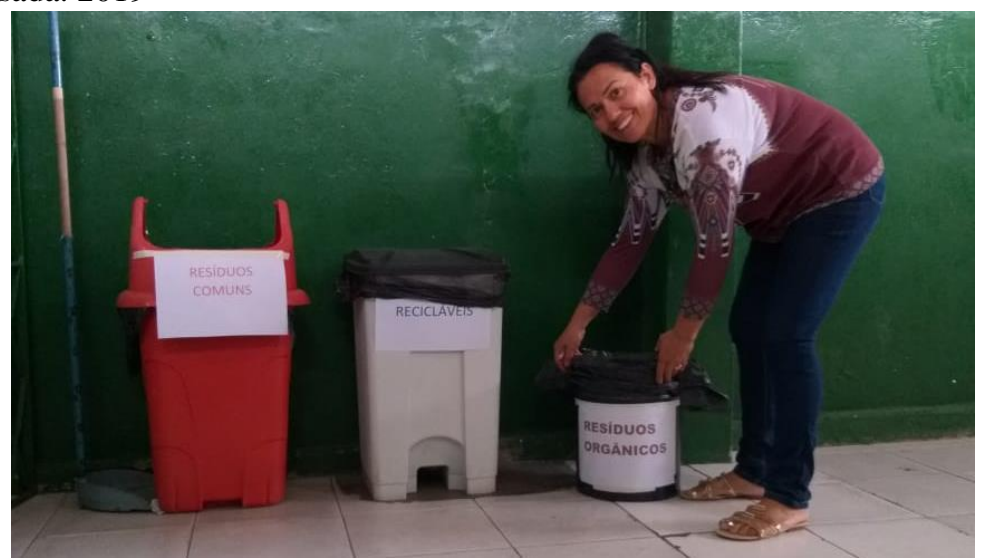


Foi solicitado aos funcionários responsáveis pela limpeza da escola, para que não recolhessem os resíduos, pois ao final do expediente matutino (de segunda a sexta-feira entre 20 e 24 de maio de 2019) a pesquisadora pudesse coletar e pesar os resíduos descartados (Figura 2). Além do pátio da escola, também tiveram os resíduos pesados no mesmo período, os resíduos recolhidos junto às quatro turmas, correspondendo aos anos finais do Ensino Fundamental, sendo duas turmas dos $8^{\circ}$ anos e duas dos $9^{\circ}$ anos no turno matutino, bem como os outros setores da escola como, secretaria, diretoria, sala de coordenação pedagógica e sala de professores.

Pois para atingir objetivo da pesquisa foi necessário analisar todos os setores de produção de resíduos e quantificá-los.

Ao final do turno foram realizadas a quantificação de todos os resíduos recicláveis gerados por cada setor pesquisado, por tipo de material reciclável (papel, plástico, vidro e metal), essa pesagem foi feita com auxílio de uma mini balança digital portátil com capacidade de precisão de $10 \mathrm{~g}$ com capacidade máxima de $50 \mathrm{~kg}$ (Figura 2).

Figura 2. Pesagem dos resíduos recolhidos na Escola pesquisada. 2019

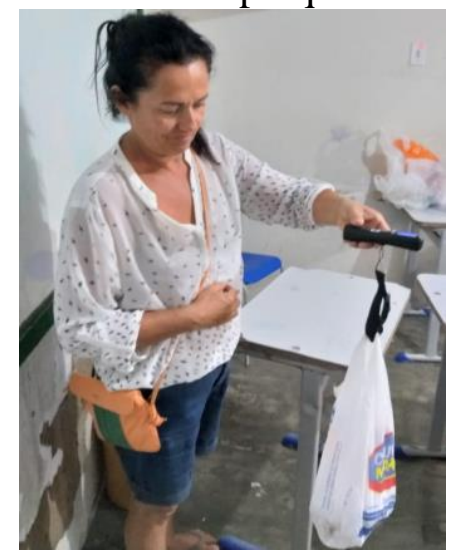

Após a coleta dos dados, os resultados foram tabulados e dispostos em quadros. A partir dos quadros foram gerados gráficos para análise dos dados de caracterização quantitativa dos resíduos sólidos produzidos nos diferentes setores da escola.

Foi aplicado à comunidade escolar um total de 81 questionários, sendo que participaram da pesquisa 3 gestores, 26 professores, 12 funcionários e 40 alunos. Antes da aplicação dos questionários houve esclarecimento prévio sobre a finalidade da pesquisa. Os questionários continham dez perguntas e tiveram algumas questões adaptadas e comparadas nos resultados desta pesquisa aos estudos de Rocha et al., (2012) e Fernandes et al. (2004), por se tratarem de estudos referentes à percepção ambiental, sendo que os professores e demais funcionários responderam ao questionário contendo questões objetivas, algumas de múltipla escolha e pelo menos uma questão subjetiva. Aos alunos foram entregues questionários contendo somente questões objetivas. 
O processo utilizado na coleta de dados se deu no mês de maio de 2019 da seguinte forma:

Inicialmente a professora pesquisadora responsável pela coleta dirigiu-se até as Gestoras da Escola (dia 27/05/2019) e apresentou o questionário fazendo as devidas orientações para o preenchimento e solicitou que até o fim do experiente eles fossem devolvidos. O mesmo procedimento se repetiu aos funcionários (dia 27/05/2019) e professores (dia 28/05/2019) da Escola.

No dia 29/05/2019 a professora pesquisadora se apresentou à escola e dirigiu-se as salas de aulas do $8^{\circ}$ e $9^{\circ}$ anos e apresentou o questionário aos alunos pesquisados onde fez as devidas orientações para preenchimento dos questionários.

O Termo de Consentimento Livre e Esclarecido foi lido, retirou-se possíveis dúvidas, posteriormente entregue e assinado previamente pelos participantes da pesquisa. Sendo assim, os questionários foram aplicados e ocorreu de forma individual nas dependências da Escola.

A duração de aplicação dos questionários foi de aproximadamente quarenta e cinco minutos (uma hora aula de acordo com a instituição), e durante este período a pesquisadora se manteve na sala onde os questionários estavam sendo respondidos.

Durante essa fase a pesquisa procurou seguir as etapas propostas por Lefèvre e Lefèvre (2005), detalhadamente:

Organização do material coletado, listagem, leitura e interpretação dos dados;

Releitura dos dados e identificação dos temas, pertinentes às questões correspondentes;

Em seguida, juntaram-se os dados segundo os elementos consideráveis (temas) que somaram ou se confirmaram num mesmo plano de expressivo; e, logo após a separação e organização em blocos de acepção para tornar possível a construção das categorias empíricas de investigação. Em todo o processo de estudo e discussão, o material foi correlacionado à literatura pertinente para dar apoio à discussão.

Nesta coleta de dados foram aplicadas as normas éticas determinadas na Resolução no 466/12 do Conselho Nacional de Saúde, na visão de garantir o anonimato dos integrantes pesquisados, assim como no seu direito no que se refere no Consentimento Livre e Esclarecido e respeito à vida, objetivando o exercício pleno da autonomia (BRASIL, 2012).

\section{RESULTADOS E DISCUSSÃO}

De acordo com a análise dos resíduos sólidos produzidos na unidade escola pesquisada no mês de maio de 2019 foi possível quantificar e identificar os resíduos gerados, sendo caracterizados em orgânicos e inorgânicos, sendo que ambos são descartados juntos aos resíduos comuns, não havendo, portanto, segregação desses resíduos antes do descarte. 
A partir dessa análise foi possível perceber que não existem coletores identificados de acordo com o tipo de resíduo produzido, distribuídos no espaço escolar e que existe apenas um coletor em cada sala. Isto pode ser explicado pelo pouco interesse da comunidade escolar para com os seus resíduos sólidos produzidos e pela não existência, até o momento, de um Programa de Coleta Seletiva nas Escolas e no município.

Desta forma, identificou-se os principais setores de geração dos resíduos sólidos recicláveis não orgânicos presentes na escola, são eles: salas de aula, pátio da escola, sala de informática, sala dos professores, sala da direção e a secretaria.

No que diz respeito ao local de descarte e acondicionamento dos resíduos sólidos, identificou-se que existia lixeiros em todos os ambientes da escola. Porém, os do pátio e da cozinha eram revestidos internamente com sacos plásticos, as dos demais setores não são revestidos, estes, são coletados diariamente pelas funcionárias responsáveis pela limpeza. Os resíduos recolhidos são transportados manualmente, armazenados na área externa da escola e nos dias de coletas são conduzidos e dispostos na rua, para serem coletados pela empresa de limpeza pública no município.

\section{CARACTERIZAÇÃO DOS RESÍDUOS SÓLIDOS}

A caracterização dos resíduos coletados na Escola pesquisada foi realizada uma semana letiva de aulas (entre 20 e 24 de maio de 2019), porém, para uma melhor mensuração da produção extrapolamos os dados para um mês, multiplicado por quatro vezes para corresponder a quatro semanas letivas (Quadro 1).

Foi possível identificar que o tipo de material reciclável mais encontrado na escola foi o papel, seguido do plástico (Quadro 1), contudo foi possível perceber uma diferença significativa quando comparamos em termos percentuais.

Quadro 1 - Detalhamento dos resíduos recicláveis quanto à origem, tipo e quantidade produzidos na Escola pesquisada no mês de agosto de 2019

\begin{tabular}{|c|c|c|c|c|c|c|}
\hline Setores de Coleta & $\begin{array}{c}\text { Papel } \\
(\mathrm{kg})\end{array}$ & $\begin{array}{c}\text { Plástico } \\
\text { (kg) }\end{array}$ & $\begin{array}{c}\text { Orgânico } \\
\text { (kg) }\end{array}$ & $\begin{array}{c}\text { Resíduos } \\
\text { Recicláveis } \\
(\mathrm{kg})\end{array}$ & $\begin{array}{c}\text { Resíduos } \\
\text { Comum } \\
(\mathrm{kg}) \\
\end{array}$ & $\begin{array}{c}\text { TOTAL } \\
(\mathrm{kg})\end{array}$ \\
\hline Sala do $8^{\circ}$ ano $\mathrm{B}$ & 0.04 & 0.08 & - & - & - & 0.12 \\
\hline Sala do $8^{\circ}$ ano $\mathrm{C}$ & 1.200 & 0.160 & - & - & - & 1.360 \\
\hline Sala do $9^{\circ}$ ano $\mathrm{A}$ & 0.08 & 0.150 & - & - & - & 0.23 \\
\hline Sala do $9^{\circ}$ ano B & 0.400 & 0.680 & - & - & - & 1.08 \\
\hline Sala de professores & - & - & 0.120 & - & 0.04 & 0.16 \\
\hline Pátio (Corredor) & - & - & - & 1.200 & 52.920 & 54.120 \\
\hline Secretaria & - & - & - & - & 2.0 & 2.0 \\
\hline Sala de coordenação & - & - & - & 0.04 & 0.02 & 0.06 \\
\hline Cozinha & - & - & 0.610 & 0.200 & 0.150 & 0.96 \\
\hline Total & 1.720 & 1.070 & 0.730 & 1.440 & 55.130 & 60,090 \\
\hline
\end{tabular}


Infelizmente ainda é notória a falta de preocupação e sensibilidade ambiental dentre os alunos, pois, mesmo no ambiente escolar, ainda lançam os resíduos no chão para que os funcionários coletem e depositem nos lixeiros. Associado a isto, existe uma cultura de consumismo, pois como se pode observar nos dados, a maioria dos resíduos foram coletados no pátio e corredores da escola.

Tais resultados não diferem da pesquisa anual sobre coleta seletiva, realizada pela CEMPRE (2018), quando expressou que as aparas de papel/papelão (21\%) correspondem aos tipos de materiais recicláveis mais coletados, seguido dos plásticos em geral (17\%), metais (9\%), vidros (8\%) e embalagens longa vida $(2 \%)$.

Os dados e a caracterização dos resíduos sólidos produzidos na instituição, no caso a escola pesquisa, são essenciais para a elaboração do PGRS, que deve obrigatoriamente conter essas informações (BRASIL, 2010).

Conforme a Lei 12.305/10, a elaboração e execução de um Plano de Gerenciamento de Resíduos Sólidos na escola poderá promover melhor aproveitamento dos resíduos produzidos, principalmente quando fundamentado no processo contínuo de educação ambiental, priorizando sempre a não geração, a redução e a reutilização antes da reciclagem, do tratamento e da disposição final.

\section{PERCEPÇÕES E COMPORTAMENTOS DOS PARTICIPANTES DA PESQUISA}

A coleta de dados e análises sobre as percepções e dos comportamentos dos envolvidos na pesquisa poderão servir para a definição dos objetivos, das metas e das estratégias, quanto às práticas de educação ambiental, para o envolvimento e o comprometimento de todos no gerenciamento adequado dos resíduos produzidos na escola pesquisada.

\subsubsection{Sobre os Gestores Pesquisados}

Todos os gestores pesquisados têm formação em pedagogia e/ou licenciaturas e atuam a mais de 15 anos na docência. São concursadas e possuem idade entre 40 e 50 anos de idade.

De Oliveira e Giordano (2018), também verificaram em seus dados que entre 2009 a 2015 a grande maioria dos diretores possuem ensino superior nas áreas de pedagogia ou licenciaturas (entre $70 \%$ e $80 \%$ ), e que essa taxa cresceu gradativamente no Brasil.

De acordo com a coleta de dados foi perguntado aos gestores quais práticas sustentáveis sobre resíduos sólidos eles adotam no cotidiano da escola e percebeu-se que houve incoerência nas respostas, a resposta da $\mathbf{G 3}$ diz não adotar nenhuma pratica diária, enquanto que a $\mathbf{G 1}$ afirmou fazer sempre a coleta e separação dos plásticos (Quadro 2). Pelas respostas percebemos que os gestores necessitam passar por 
formação permanente em Educação Ambiental, para entenderem mais o tema, e posteriormente tornaremse mais sensíveis a causa ambiental e assim promover a mudanças significativas no ambiente escolar, pois, sabemos que como dirigentes, poderão implantar a mudança de hábitos que a escola necessita.

Quadro 2 - Respostas dos gestores pesquisados sobre as práticas sustentáveis adotadas no cotidiano. 2019

\begin{tabular}{|c|c|}
\hline Pesquisados & Falas dos Pesquisados \\
\hline G1 & "Sempre coleto os plásticos (sacolas) separados" \\
\hline G2 & "Racionalização no descarte de resíduos" \\
\hline G3 & "Não adotamos nenhuma prática diária" \\
\hline
\end{tabular}

Esses resultados se assemelham aos dados de Luiz et al. (2013), que em um estudo sobre as atividades socioambientais praticadas por um Instituto Federal de Educação em Santa Catarina, verificouse que os resultados apresentados evidenciaram que a gestão dos resíduos gerados pela Instituição ainda não é totalmente funcional. O lixo é separado por empresa terceirizada para executar os serviços de limpeza.

Quando perguntado quais propostas que a gestão apresenta para os resíduos sólidos produzidos na escola, viu-se interesse de todos os gestores em realizar um trabalho de manejo adequado com o lixo, o que aponta expectativas positivas, sendo mais enfática a resposta do $\mathbf{G 2}$ quando fala na participação mais efetiva na conscientização dos alunos (Quadro 3).

Quadro 3 - Respostas dos gestores pesquisados a Gestão dos Resíduos Sólidos na escola. 2019

\begin{tabular}{|c|c|}
\hline Pesquisados & Falas dos Pesquisados \\
\hline G1 & "Que seja separada de forma correta” \\
\hline G2 & "Participação mais efetiva na conscientização dos alunos" \\
\hline G3 & "Conscientização, e que possamos praticar pelo menos a divisão do lixo seco do molhado" \\
\hline
\end{tabular}

Nas respostas dadas pelos gestores sobre quais práticas sustentáveis são aplicadas aos resíduos sólidos eles adotam em seu cotidiano na escola, percebe-se uma visão fragmentada e, muitas vezes, sem uma aplicabilidade real, demonstrando uma falta de compreensão sobre gestão de resíduos sólidos, sendo, portanto, urgente à adoção de medidas para que estes gestores, também, recebam uma formação continuada a respeito do tema em voga.

De acordo com Santos et al. (2018), o fundamental é que exista um desenvolvimento de um consumo mais sustentável e de soluções para gestão de resíduos sólidos, devem ser promovidos e incentivados no âmbito educacional, sendo capazes de desenvolver crianças e adultos como cidadãos conscientes, ponto importante para criação de uma população mais participativa na gestão de resíduos.

\section{Sobre os Professores Pesquisados}


Quanto ao gênero dos professores pesquisados a maioria foi do sexo feminino (54\%), com idade entre 21 e 56 anos, todos tendo cursado curso superior (Licenciatura) e 50\% já cursaram uma PósGraduação e apenas um dos pesquisados leciona disciplina diferente de sua área de formação.

Estes dados correspondem ao estudo de Conceição (2015), na cidade de Camaçari-BA, onde participaram da pesquisa 12 professores, sendo 2 homens e 10 mulheres, todos com idade entre 30 e 50 anos, quanto ao nível de escolaridade, $92 \%$ possuem especialização.

Questionou-se também os professores a respeito da preocupação destes profissionais com relação aos problemas ambientais que acometem a sociedade, todos expressaram possuir de preocupação em relação à problemática ambiental, sendo que $81 \%$ expressou ser em um nível elevado e 19\% médio nível de preocupação. Essa percepção e sensibilização para as questões ambientais oportunizem o desenvolvimento de um plano de ação na instituição, pois este é um dos problemas ambientais que acometem a sociedade e necessitam do envolvimento mais efetivo, principalmente da escola.

Esses resultados corroboram com a pesquisa de conforme Carvalho (2012), pois para uma formação de atitudes ecológicas e cidadãs é necessário o desenvolvimento de capacidades e sensibilidades para identificar e compreender os problemas ambientais, de maneira a assumir um posicionamento e comprometer-se com a tomada de decisões.

$\mathrm{Na}$ percepção dos professores pesquisados, a Sociedade (46\%) é a principal responsável pela gestão dos Resíduos Sólidos Urbanos (RSU) no município, sendo seguida pelo Governo com (35\%), 11\% disseram ser do Governo e da Sociedade e 8\% da Empresa de limpeza pública municipal.

Tais respostas evidenciam que os pesquisados têm a consciência de que o problema dos resíduos sólidos também é responsabilidade da sociedade, e quanto aos resíduos sólidos a Lei n ${ }^{\circ}$ 12.305/10, em seu art.30 estabelece a responsabilidade compartilhada pelo ciclo de vida dos produtos aos fabricantes, importadores, distribuidores, comerciantes e inclui os consumidores, além dos titulares dos serviços de limpeza pública (BRASIL, 2010).

Sobre a responsabilidade do descarte adequado dos resíduos sólidos produzidos no cotidiano, 96\% disseram que se sentem responsáveis e $4 \%$ não se veem responsáveis.

Esses dados expressam a mesma tendência do estudo de Carvalho (2012), além do mais demonstra que estão antenados com a Política Nacional de Resíduos Sólidos, cuja Lei considera ser um ponto importante para o processo de gerenciamento dos resíduos dentro da instituição, a consciência que todos os cidadãos que são responsáveis pela conservação do ambiente, uma vez que a responsabilidade compartilhada pelo ciclo de vida dos produtos é um dos princípios da PNRS e se estende também aos consumidores (BRASIL, 2010). 
Ao serem indagados sobre se costumam trabalhar com temas relacionados às questões ambientais em sala de aula, 95\% disseram que "sim" e 5\% "não". Resultado muito importante, pois, demonstra a preocupação dos professores em trabalhar determinado tema transversal, independentemente da disciplina que leciona.

Tais resultados expressam um aspecto muito importante, até mesmo porque o tema Meio Ambiente é estabelecido como um eixo transversal pelos Parâmetros Curriculares Nacionais - PCN (BRASIL, 1997), não devendo ser trabalhado apenas por uma disciplina específica.

Sobre a participação em algum projeto voltado para a questão dos resíduos sólidos, 85\% dos professores pesquisados disseram que já participaram e 15\% não participaram. Mesmo assim, estes dados expressam questionamentos, pois deve haver o cuidado de não desenvolver um trabalho direcionado para essa temática reduzindo-o apenas a coleta seletiva na escola.

De acordo com Baeta et al. (2002), os diversos Programas de Educação Ambiental que trabalham essa temática nas escolas deveriam promover a reflexão crítica dos aspectos envolvidos nas questões ambientais locais e globais, mas ao invés disso, abordam apenas a necessidade de uma coleta seletiva cujo destino final dos resíduos, hoje no Brasil, ainda são os lixões.

Dentre os professores que participaram da pesquisa, 62\% disseram fazer separação dos resíduos sólidos orgânicos dos resíduos inorgânicos antes de descartá-los, contudo, 73\% afirmaram não participar de Programas de coleta seletiva no município.

No Brasil em 2013, conforme a pesquisa do Sistema Nacional de Informações sobre Saneamento SNIS, dos 3.275 municípios que participaram do estudo, apenas 32,5\% possuíam iniciativas de coleta seletiva, demonstrando que esse tipo de iniciativa precisa ser ampliado. Sendo de crucial importância associar a separação desses resíduos com a coleta seletiva, para que os resíduos não sejam misturados, favorecendo, assim a reciclagem (BRASIL, 2013).

Sobre se considerarem consumistas, 62\% disseram que "não" e 38\% "sim". Mesmo com essas respostas, trata-se de uma questão que merece maior atenção e debate por parte de toda comunidade escolar, considerando que a produção de resíduos sólidos e a disposição inadequada comprometem a qualidade do meio ambiente. Muitas vezes as respostas não condizem com a real postura dos pesquisados, uma vez que sabem que afirmar que são consumistas acarretaria uma maior quantidade de resíduos descartados desse consumo.

Segundo Barbosa e Ibrahin (2014), atualmente o padrão de produção e consumo dessa sociedade ultrapassa significativamente as necessidades básicas. Muito embora, pessoas insistam a não se considerarem consumistas, a tendência atual é que essa sociedade consuma muito além das reais 
necessidades, sendo esse um ponto importante para reflexão crítica e a reavaliação com relação ao atendimento de necessidades básicas e do que possa ser considerado supérfluo.

Quando perguntado aos professores que práticas sustentáveis são adotadas no cotidiano, percebese que a maioria adota práticas que proporciona ganhos ao meio ambiente e só poucos, como o P10 e o P26, não adotam práticas sustentáveis e destaca-se a justificativa do $\mathbf{P 2 6}$ que diz ser porque o município não possui coleta seletiva tirando de si a responsabilidade (Quadro 4).

Quadro 4. Respostas dos professores pesquisados sobre quais práticas sustentáveis são adotadas por eles no seu cotidiano. Barra de Santa Rosa-PB. 2019

\begin{tabular}{|c|c|}
\hline Pesquisados & Falas dos Pesquisados \\
\hline P1 & "Os resíduos sólidos, separo para entregar a um catador que peça na minha residência" \\
\hline P2 & "Resto de alimentos coloco nas plantas(cascas), alimento para galinhas" \\
\hline P3 & "Separação" \\
\hline P4 & "Separo do lixo doméstico os materiais reciclados" \\
\hline P5 & "Costumo usar lixo orgânico como adubo e utilizo alguns tipos de material para ornamentação" \\
\hline P6 & "Separação correta dos resíduos, conscientização" \\
\hline P7 & "Separar os residuos orgânicos dos inorgânicos. Priorizar a coleta seletiva" \\
\hline P8 & "Separar os resíduos sólidos, reaproveitamento e reciclagem de resíduos que tiveram como destino o lixo" \\
\hline P9 & "Separar o lixo orgânico dos produtos recicláveis e entregá-los limpos" \\
\hline P10 & "Infelizmente não estou tendo nenhuma pratica quanto o descarte" \\
\hline P11 & "Separar corretamente os resíduos" \\
\hline P12 & "Separar adequadamente os resíduos produzidos em casa" \\
\hline P13 & "Evito utilizar materiais que não são beneficentes ao meio ambiente o máximo possivel" \\
\hline P14 & "Separo o lixo orgânico do lixo comum, guardo garrafas pet para catadores" \\
\hline P15 & "Reaproveitamento de materiais evitando a formação de muitos resíduos" \\
\hline P16 & $\begin{array}{l}\text { "A sustentabilidade depende do trabalho em conjunto: Poder público, sociedade, governantes, pois, está ainda } \\
\text { no papel diante das dificuldades o trabalho, a informação, sobre esse assunto segue em caráter informacional, } \\
\text { relatando a preservação do meio ambiente no tocante as práticas sustentáveis" }\end{array}$ \\
\hline P17 & "Evitar o máximo possivel o consumo de produtos que gerem resíduos" \\
\hline P18 & "Principalmente descartar os resíduos sólidos em locais adequados" \\
\hline P19 & "Descarte adequado de alguns resíduos" \\
\hline P20 & "A separação de materiais recicláveis e faço a doação para catadores de uma associação" \\
\hline P21 & "Descarte de pilhas e baterias em locais especificos" \\
\hline P22 & $\begin{array}{c}\text { "Em casa é separado como prática cotidiana o lixo orgânico do inorgânico, porem a separação dos resíduos } \\
\text { ainda não é de forma adequada" }\end{array}$ \\
\hline $\mathbf{P 2 3}$ & "A seleção de resíduos etc." \\
\hline P24 & "Separar os resíduos, como por exemplo latas e garrafas pet" \\
\hline P25 & "Evito produtos descartáveis sempre que possível faço doações" \\
\hline P26 & "Não adoto, pois o municipio não possui coleta seletiva" \\
\hline
\end{tabular}

Para Logarezzi (2006), a Educação Ambiental também deve abordar a questão do consumo discutindo o conceito de necessidade e a real função do consumo, frente à tendência cultural da sociedade, destacando a responsabilidade e a importância das ações individuais e coletivas.

No que diz respeito à Educação Ambiental, na temática práticas sustentáveis de resíduos sólidos urbanos, as ações e práticas dependem muito da visão dos docentes, do conjunto de percepções/ representações e da habilidade dos professores em relacioná-la com o ambiente ao seu redor, que é favorecida a partir das experiências vividas. Porém, corriqueiramente, em consequência do caminho 
árduo da profissão e a dificuldade em relacionar a temática ambiental com os conteúdos curriculares, muitos docentes acabam não dando a devida importância ao tema (SILVA, 2017).

De acordo com Gazzinelli (2002)

[...] a ação dos sujeitos está invariavelmente condicionada pelas suas representações, como se fosse possível deduzir posturas e práticas dos sujeitos a partir de um tecido de representações. [...] Não são apenas as representações que definem as práticas, mas a partir delas podem ser construídos novos modos de pensamento que desafiem os padrões de relacionamento entre o homem e o ambiente. (GAZZINELLI, 2002, p. 179).

As respostas dos professores pesquisados demonstram que uma parcela significativa deles possui um conhecimento limitado sobre práticas sustentáveis ambientais, fato preocupante, pois os professores são um dos principais atores no processo de formação do aluno para um pensamento crítico e sensibilizado em relação às questões ambientais referentes à produção e destinação dos resíduos.

Analisando as respostas dadas pelos professores quando perguntado quais propostas adequadas que a gestão pode adotar para os resíduos sólidos produzidos na escola, foram dadas sugestões relevantes como a P21, que propôs obrigatoriedade em cumprir a coleta seletiva escolar, porém, houve outras inocorrentes, como a P23 que sugere a gestão extinguir a produção de alguns resíduos tóxicos (Quadro 5). Sobre os resíduos tóxicos, a escola não produz tais resíduos e com isso, a gestão escolar não detém de competência para extinguir esse tipo de resíduos produzido na Cidade, Estado e/ou País.

Quadro 5. Respostas dos professores participantes da pesquisa sobre quais propostas adequadas que a gestão pode adotar para os resíduos sólidos produzidos na escola. 2019

\begin{tabular}{|c|c|}
\hline Pesquisados & Falas dos Pesquisados \\
\hline $\mathbf{P 1}$ & $\begin{array}{c}\text { "Promover um projeto permanente sobre a problemática e construir a prática cotidiana da separação dos } \\
\text { resíduos na escola" }\end{array}$ \\
\hline $\mathbf{P 2}$ & "Sensibilizar a população a separar o seu lixo, facilitando para os catadores" \\
\hline P3 & "Não tenho" \\
\hline $\mathbf{P 4}$ & "Sensibilizar os alunos, perante os problemas ocasionados pelo descarte inadequado dos resíduos sólidos" \\
\hline P5 & "Projetos, palestras e apresentação de projetos possíveis de executar só pela escola" \\
\hline P6 & "Orientação de maneira flexível para toda comunidade escolar" \\
\hline P7 & $\begin{array}{c}\text { "Faço minha parte e também a trabalho de conscientização junto ao corpo discente das instituições de ensino } \\
\text { nas quais sou docente" }\end{array}$ \\
\hline P8 & "conscientização dos alunos projetos relacionados as práticas ambientais" \\
\hline P9 & $\begin{array}{c}\text { "Separação dos tipos de lixo e que seja descartado apenas os que não se possa reciclar, pedir que os } \\
\text { catadores venham recolher os resíduos sólidos antes da coleta do municipio" }\end{array}$ \\
\hline P10 & $\begin{array}{c}\text { "Coleta seletiva, onde a sociedade separasse os residuos em sua casa e que a coleta acontecesse de forma } \\
\text { adequada" }\end{array}$ \\
\hline P11 & "Palestras, aulas sobre a coleta seletiva, dia "D", projetos, etc" \\
\hline P12 & "Descarte correto do lixo; conscientização dos alunos a respeito da temática" \\
\hline P13 & "Não deixar de esclarecer sua importância" \\
\hline P14 & "Instruir professores e funcionários de como separar corretamente o lixo orgânico e inorgânico" \\
\hline P15 & "Promoção de conscientização via educação" \\
\hline P16 & "Palestras, oficinas, videos, aulas de campo, trabalhos que envolvem a sociedade" \\
\hline P17 & "Separação do lixo que pode ser reciclado e fazer parcerias com catadores para recolherem" \\
\hline P18 & $\begin{array}{c}\text { "Ações de educação ambiental no sentido de sensibilizar as pessoas quanto a importância do descartar } \\
\text { adequado dos resíduos sólidos. } \\
\text { Formar associações de catadores de lixo. } \\
\text { Promover } \backslash \text { ações do tipo3Rs (reduzir, reciclar e reutilizar). }\end{array}$ \\
\hline
\end{tabular}




\begin{tabular}{|c|c|}
\hline & $\begin{array}{r}\text { Obter formas adequadas para o descarte dos resíduos sólidos coletados no município. } \\
\text { Inserir a Educação Ambiental como política permanente no município. }\end{array}$ \\
\hline P19 & "Coleta seletiva dos resíduos sólidos e saneamento básico de qualidade" \\
\hline P20 & "Conscientizar toda a comunidade escolar para a prática da separação dos resíduos da nossa escola" \\
\hline P21 & "Obrigatoriedade em comprimento da coleta seletiva escolar, em coleta seletiva nos carros coletores, \\
capacitação ao pessoal especializado da coleta"
\end{tabular}

Conforme Souza (2015), a disposição final dos resíduos orgânicos em lugares inadequados pode afetar também a saúde dos seres humanos, por causa dos gases que são emitidos pelo processo de decomposição como: metano, dióxido de carbono, sulfídrico, amônia e outros ácidos orgânicos voláteis. Apenas $10 \%$ do total coletado têm como destino final os aterros sanitários, onde se diferencia pelo tratamento do chorume. Sendo que algumas cidades brasileiras atiram o lixo nas ruas, terrenos baldios, rios, lagos, lagoas e no mar.

Nesta perspectiva, a EA tem uma importância fundamental, pois permite a solução de vários problemas em nossa vida e novas ideias para a comunidade. Em concordância com essa ideia, Zuben (1998) afirma que o projeto de coleta seletiva nas escolas é muito importante, pois incentiva os alunos desde já a separarem o lixo, levando esse hábito para suas casas. Por isso o autor destaca que uma das principais alternativas para diminuir o problema do lixo é a reciclagem. Portanto, a EA deve ser praticada desde o Ensino Fundamental.

De acordo com Carvalho (2012) para que possamos desenvolver atitudes ecológicas e cidadãs torna-se crucial o desenvolvimento de capacidades e sensibilidades para identificar e compreender os problemas ambientais, de maneira a assumir um posicionamento e comprometer-se com a tomada de decisões.

\section{Sobre os funcionários Pesquisados}

Os funcionários participantes em sua maioria são do gênero feminino e numa faixa de idade entre 31 a 57 anos conforme está apresentado no Quadro 6. Quanto ao de escolaridade a maioria apresenta tem ensino superior incompleto e/ou ensino médio completo. Em relação ao nível de preocupação com relação aos problemas ambientais, os dados mostram que a maioria tem nível médio de preocupação e apenas 2 tem alto nível de preocupação.

Quadro 6. Perfil dos funcionários pesquisados quanto à idade e gênero. 2019

\begin{tabular}{|c|c|c|c|}
\hline \multirow{2}{*}{ Pesquisados } & \multirow{2}{*}{ Idade } & \multicolumn{2}{|c|}{ Gênero } \\
\cline { 3 - 4 } & & Masculino & Feminino \\
\hline F1 & 31 & - & $\mathrm{x}$ \\
\hline F2 & 34 & - & $\mathrm{x}$ \\
\hline F3 & 35 & $\mathrm{x}$ & - \\
\hline
\end{tabular}




\begin{tabular}{|c|c|c|c|}
\hline F4 & 40 & - & $\mathrm{x}$ \\
\hline F5 & 42 & $\mathrm{x}$ & - \\
\hline F6 & 47 & - & $\mathrm{x}$ \\
\hline F7 & 48 & - & $\mathrm{x}$ \\
\hline F8 & 52 & - & $\mathrm{x}$ \\
\hline F9 & 53 & $\mathrm{x}$ & - \\
\hline F10 & 54 & - & $\mathrm{x}$ \\
\hline F11 & 55 & $\mathrm{x}$ & - \\
\hline F12 & 57 & - & $\mathrm{x}$ \\
\hline \multicolumn{2}{|l}{ Total } & $\mathbf{4}$ & $\mathbf{8}$ \\
\hline
\end{tabular}

Quando indagados sobre quem é o maior responsável pela conservação do meio ambiente, $88 \%$ responderam ser o ser humano e $12 \%$ responsabilizou o governo. Percebe-se aqui que quase todos isentam a responsabilidade do poder público e assume o discurso da transferência da responsabilidade social apenas para a população.

Ao serem questionados sobre quem é o principal responsável pela gestão dos resíduos sólidos urbano na cidade, $58 \%$ responderam que é a Sociedade e $42 \%$ disseram ser o Governo.

Sobre qual o principal destino dos resíduos sólidos produzidos no seu local de trabalho, todos os 12 responderam ser o Lixão. Esta resposta mostra que eles desconhecem a legislação pertinente e respondem de acordo com a realidade local, cujos resíduos sólidos no município da pesquisa tem como destino final um lixão.

Os funcionários pesquisados foram indagados sobre como eles se sentem responsáveis pelo descarte adequado dos resíduos sólidos que produz no seu cotidiano e 10 deles disseram que se acham responsáveis e 2 não se sentem com essa responsabilidade.

Em relação às práticas sustentáveis que eles adotam no cotidiano sobre os resíduos sólidos produzidos na escola e em suas residências, 6 dizem evitar desperdícios, 3 reutilizam embalagens, 1 evita descartáveis, 1 não adota nenhuma prática. Esses resultados demonstram que eles fazem uma pequena ação e não dominam as questões ambientais de forma mais consciente se isentado de suas responsabilidades enquanto seres sociais e políticos.

Questionou-se os funcionários sobre quais as diferenças entre resíduos e rejeitos e 11 responderam saber a diferença entre resíduos sólidos e rejeitos e 1 não sabe diferenciar. Porém, dos que responderam saber as diferenças, ninguém soube conceituar nenhum dos termos.

A mesma situação ocorreu quando os funcionários pesquisados foram perguntados se costumam separar resíduos orgânicos dos resíduos inorgânicos antes de descartá-los. 5 responderam que sim e 7 não.

Quando foram indagados sobre se eles contribuem com algum Programa de coleta seletiva, seja no condomínio, bairro ou município, a maioria afirmou que contribui no Programa de coleta seletiva e 2 responderam não contribuírem, apresentando uma diferença significativa entre ao que contribui e os que não contribui. 
Quando perguntado quais principais problemas relacionado aos resíduos, cada um dos participantes apontou problemas relevantes que merece atenção e destaca-se a resposta do F9 que diz faltar políticas públicas dos entes federativos e da sociedade (Quadro 7).

Quadro 7. Principais problemas relacionados aos resíduos sólidos segundo os pesquisados. 2019

\begin{tabular}{|c|c|}
\hline Pesquisados & Falas dos Pesquisados \\
\hline F1 & $\begin{array}{c}\text { "Os resíduos orgânicos, como restos de alimentos são descartados de forma errada, que o correto seria á } \\
\text { compostagem" }\end{array}$ \\
\hline F2 & "Os estudantes não costumam colocar o lixo na lixeira" \\
\hline F3 & "Falta de um aterro sanitário adequado para o nosso município" \\
\hline F4 & $\begin{array}{c}\text { "No colégio os estudantes não costumam usar as lixeiras para descartar o seu próprio lixo e acabam } \\
\text { jogando tudo no chão" }\end{array}$ \\
\hline F5 & "Não ter um local especifico para separar rejeitos e outros" \\
\hline F6 & "Falta mais orientação para sociedade, para fazer sua coleta seletiva, reutilização" \\
\hline F7 & "O maior problema é a sociedade não caminhar em mesma direção da gestão" \\
\hline F8 & $\begin{array}{c}\text { "Falta de orientação, para ser separados esses residuos. Restos de alimentos descartado De forma errada, } \\
\text { como computador" }\end{array}$ \\
\hline F9 & "A falta de políticas públicas, pelos entes federativos e também da sociedade" \\
\hline F10 & "Falta uma coleta seletiva, sensibilização a comunidade, melhoria no destino final do lixo" \\
\hline F11 & $\begin{array}{c}\text { "Os coletadores se cortam com os vidros, entope bueiros, os catadores rasgam sacolas para tirar os que eles } \\
\text { precisam e que serve como reciclado" }\end{array}$ \\
\hline F12 & "Os aparelhos eletrônicos que não são usados mais, não dá os destino certo" \\
\hline
\end{tabular}

Com isso, de acordo com Mesquita et al. (2011), pode-se dizer que, mesmo com as questões ambientais sendo globalmente difundidas, os comportamentos individuais ainda estão muito aquém do necessário para uma cultura sustentável, demandando mudanças de comportamentos individuais e coletivos.

O aperfeiçoamento profissional e a formação do funcionário de escola na sua especificidade como educador - possibilita superar o preconceito conservador que os coloca como meros executores de tarefas, tornando-os conscientes de seu papel de agentes ativos na realização da função social da educação escolar. Pois, “[...] diante das novas exigências sociais e dos instrumentos democráticos já disponíveis, é preciso construir uma proposta para inserir os funcionários das escolas na função de educador”. (APP, 2002, p.1).

É de fundamental importância a necessidade de formação continuada para todos os atores envolvidos, e não somente para professores e alunos. Essa colocação é muito relevante, pois como afirmou Dias (2003, p. 73) ao dizer que "Capacitar em EA significa capacitar os elementos que fazem funcionar a escola, os diretores, os coordenadores, os professores e o pessoal de apoio". 


\section{Sobre os alunos Pesquisados}

Dentre os alunos que se dispuseram a participar da pesquisa, $62,5 \%$ são do gênero feminino e $37,5 \%$ alunos do masculino, todos com faixa etária de 12 a 16 anos e cursando o $8^{\circ}$ e $9^{\circ}$ anos das séries finais do Ensino Fundamental (Quadro 8). Foi possível detectar através dessa pesquisa que uma parcela significativa dos alunos que participaram da pesquisa demonstrou interesse no estudo desde a fase de caracterização quanti-qualitativa dos resíduos produzidos na escola.

Quadro 8. Perfil dos alunos pesquisados quanto a idade e gênero por turma. 2019

\begin{tabular}{|c|c|c|c|c|}
\hline \multirow{2}{*}{ Turmas Pesquisadas } & \multirow{2}{*}{ Idade } & \multirow{2}{*}{ Quantidade } & \multicolumn{2}{|c|}{ Gênero } \\
\hline & & & Masculino & Feminino \\
\hline \multirow{3}{*}{$8^{\circ}$ ano $B$} & 13 anos & 5 & 1 & 4 \\
\hline & 14 anos & 4 & 3 & 1 \\
\hline & 15 anos & 1 & - & 1 \\
\hline \multirow{4}{*}{$8^{\circ}$ Ano C } & 12 anos & 2 & - & 2 \\
\hline & 13 anos & 4 & 1 & 3 \\
\hline & 14 anos & 2 & 1 & 1 \\
\hline & 15 anos & 2 & 2 & - \\
\hline \multirow{3}{*}{$9^{\circ}$ Ano A } & 13 anos & 1 & - & 1 \\
\hline & 14 anos & 8 & 3 & 5 \\
\hline & 15 anos & 1 & - & 1 \\
\hline \multirow{4}{*}{$9^{\circ}$ Ano B } & 13 anos & 2 & 1 & 1 \\
\hline & 14 anos & 5 & 2 & 3 \\
\hline & 15 anos & 2 & - & 2 \\
\hline & 16 anos & 1 & 1 & - \\
\hline \multicolumn{2}{|c|}{ Total } & 40 & 15 & 25 \\
\hline
\end{tabular}

De acordo com a Política Nacional de Educação Ambiental - PNEA, em seu artigo 10, “a Educação Ambiental será desenvolvida como uma prática educativa integrada, contínua e permanente em todos os níveis e modalidades do ensino formal" (BRASIL, 1999).

Observamos, assim a legalidade e a legitimidade da Educação Ambiental no contexto educativo, sendo assegurada por uma legislação específica e que prevê a formação integral, contínua e permanente de todos os alunos durante todo o seu período de inserção no Ensino Formal.

A primeira questão foi em relação à referência que os estudantes possuem em relação ao meio ambiente. A maioria, $72,5 \%$ associou o termo a tudo que nos rodeia, à medida que apenas $25 \%$ relacionam o conceito à natureza (Figura 3).

Figura 3. Respostas dos alunos pesquisados sobre a definição do termo "Meio Ambiente”. 2019 


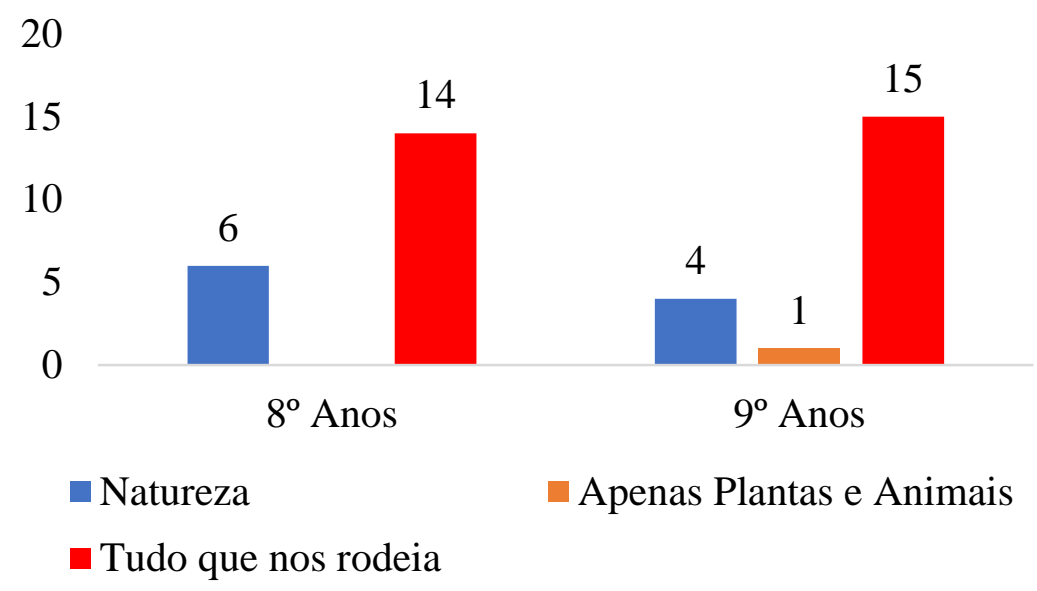

De acordo com Carvalho (2012), esse sentimento é importante pois coloca o meio ambiente frequentemente associado apenas a plantas, animais, natureza, como se fosse independente da interação com o homem.

Ao serem indagados sobre o nível preocupação em relação às questões ambientais, foram dispostas as alternativas baixa, média e alta, sendo que $62,5 \%$ responderam possuir médio nível de preocupação, enquanto os outros $37,5 \%$ responderam possuir um nível alto de preocupação com as questões ambientais (Figura 4).

Figura 4. Respostas dos alunos pesquisados sobre a preocupação em relação aos problemas ambientais. 2019

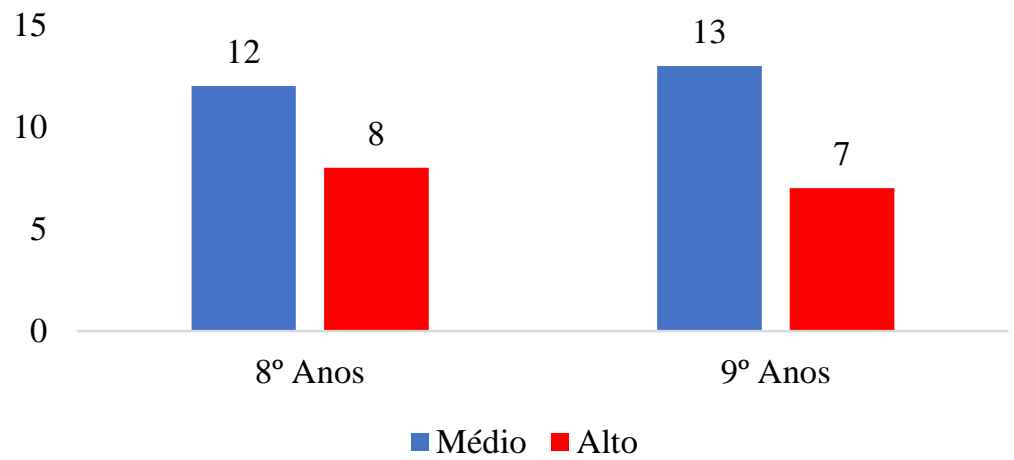

Sobre a conservação do meio ambiente, $85 \%$ dos alunos consideram a sociedade como principal responsável (Figura 5). Essa percepção é importante para atuação consciente desses cidadãos, que precisam mais do que nunca repensar os valores e práticas dessa sociedade, evidenciando que a EA é um processo importante nessa atuação como cidadão.

Figura 5. Respostas dos alunos pesquisados sobre quem é o responsável pela conservação do meio ambiente. 2019 


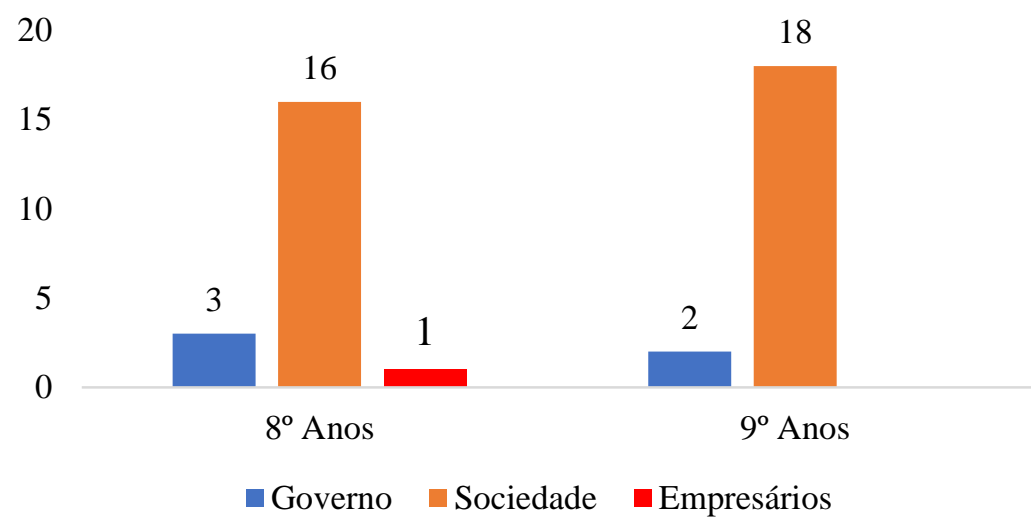

Na visão de Jacobi (2003), a educação ambiental possibilita repensar essas práticas e o papel do professor como mediadores no processo de formação de indivíduos que compreendam a interdependência que existe nas questões ambientais e a responsabilidade de cada cidadão na construção de uma sociedade sustentável.

Dos alunos pesquisados, 82,5\% disseram ser o lixão o principal destino dos resíduos sólidos produzidos no município (Figura 6). Esse resultado se deve à cidade não possuir um Aterro Sanitário, ainda em funcionamento.

Figura 6. Respostas dos alunos pesquisados sobre o destino dos resíduos sólidos produzidos no seu município. 2019

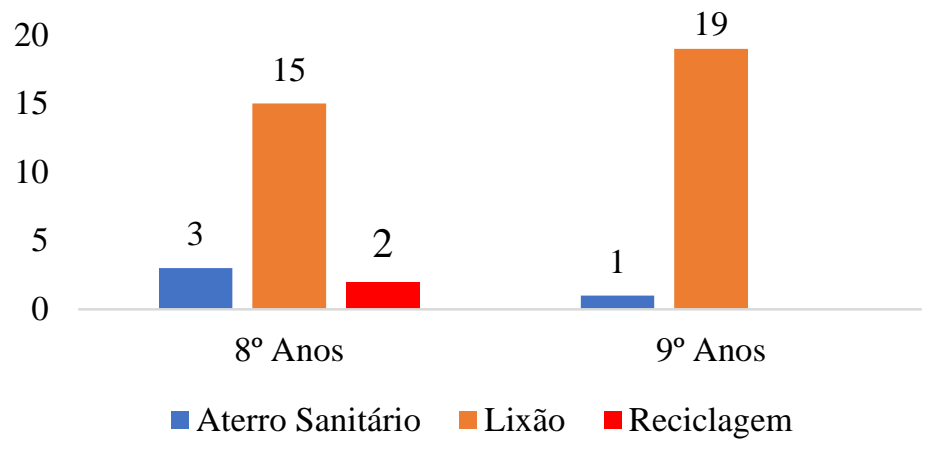

Esses resultados seguem a mesma tendência do estudo de Rocha et al. (2012) sobre a percepção ambiental de estudantes no que concerne à gestão integrada de resíduos sólidos, onde constataram que quando perguntados a respeito da destinação final dos resíduos produzidos no bairro, a maioria dos pesquisados responderam desconhecer o destino, 32\% indicaram o lixão, $22 \%$ responderam o aterro sanitário e $9 \%$ aterro controlado.

Ao serem indagados sobre a diferença entre resíduos sólidos e rejeitos, $60 \%$ dos alunos afirmaram desconhecer a diferença entre os termos (Figura 7).

Figura 7. Respostas dos alunos pesquisados sobre a diferença entre resíduos sólidos e rejeitos. 2019 


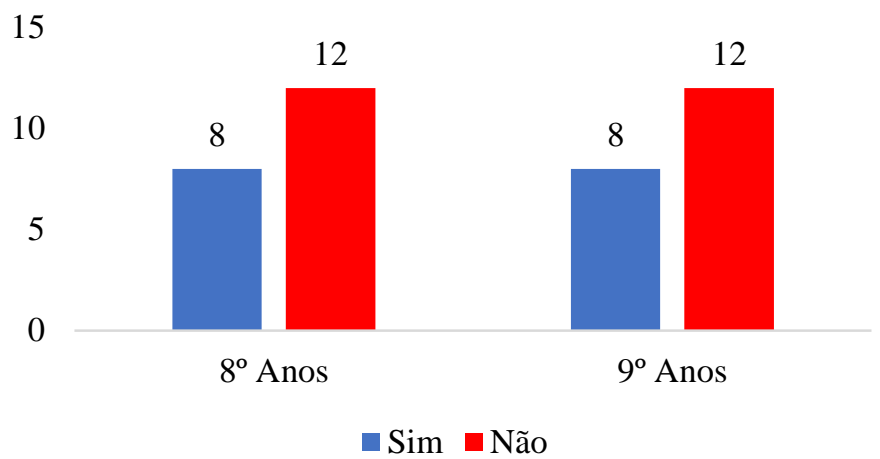

Essa resposta expressa claramente que os alunos não têm conhecimento ou domínio sobre a Lei 12.305/10 art. $3^{\circ}$ (Lei Política Nacional de Resíduos Sólidos - PNRS), que distingue claramente a diferença entre esses conceitos. Os rejeitos não são passíveis de reaproveitamento, portanto só apresentam como alternativa à disposição final ambientalmente adequada em aterros sanitários, enquanto os resíduos resultantes das atividades da sociedade podem e devem ser reaproveitados.

Quanto à identificação dos resíduos que são recicláveis, foram dispostas algumas alternativas para que os alunos respondessem, sendo que 55\% conseguiram apontar apenas os resíduos recicláveis, 45\% assinalaram tanto os materiais recicláveis quanto os não recicláveis (Figura 8), dessa forma, apenas uma pouco mais que a metade alunos conseguiu identificar apenas os resíduos recicláveis.

Figura 8. Respostas dos alunos pesquisados sobre quais produtos são recicláveis. 2019

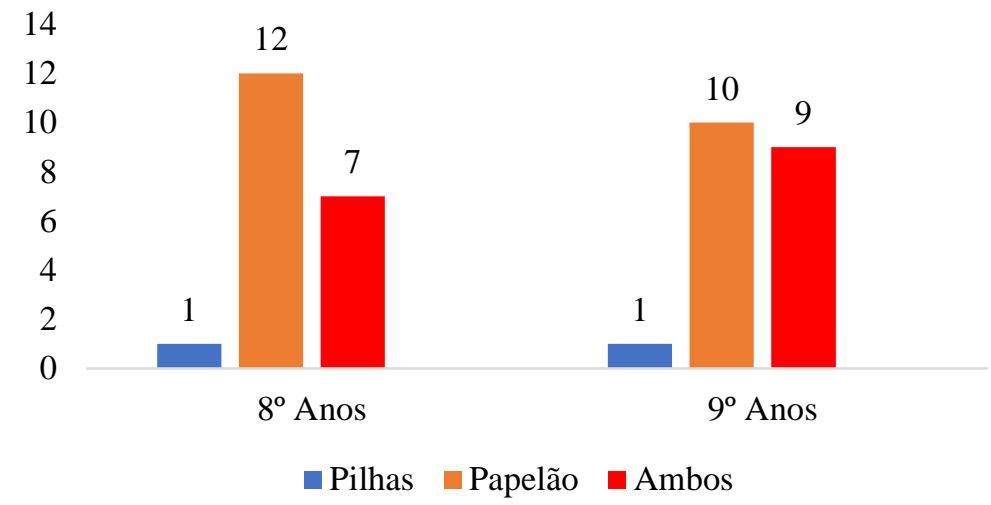

Quanto ao sentimento de responsabilidade quanto ao correto descarte dos resíduos sólidos que produzem 62,5\% dos estudantes disse sentirem-se responsáveis (Figura 9). Esse resultado é preocupante pois demonstra, mais uma vez, a falta de sensibilização e conscientização ambiental dos pesquisados.

Figura 9. Respostas dos alunos pesquisados sobre a responsabilidade pelo descarte correto dos resíduos sólidos que produz no seu cotidiano. 2019 


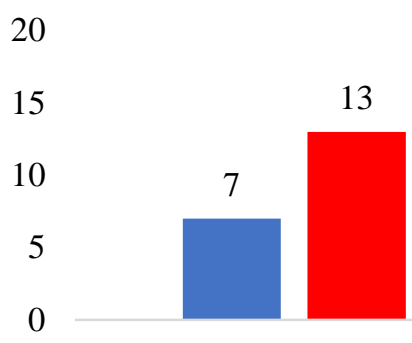

$8^{\circ}$ Anos
18

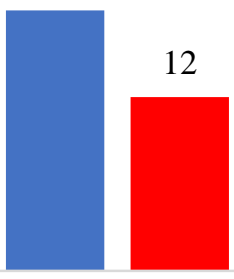

$9^{\circ}$ Anos

- Sim não

Ao serem indagados sobre a separação dos resíduos sólidos orgânicos dos resíduos inorgânicos antes de descartá-los, $50 \%$ dos discentes participantes da pesquisa responderam que fazem e os outros $50 \%$ que não fazem (Figura 10).

Outro dado importante, pois durante as atividades da pesquisa na escola e dentro das salas de aula foi possível ser observado que em alguns alunos jogaram os resíduos de forma aleatória nas lixeiras e/ou no chão das salas e do pátio.

Figura 10. Respostas dos alunos pesquisados sobre a separação dos resíduos orgânicos dos resíduos inorgânicos antes de descartá-los. 2019

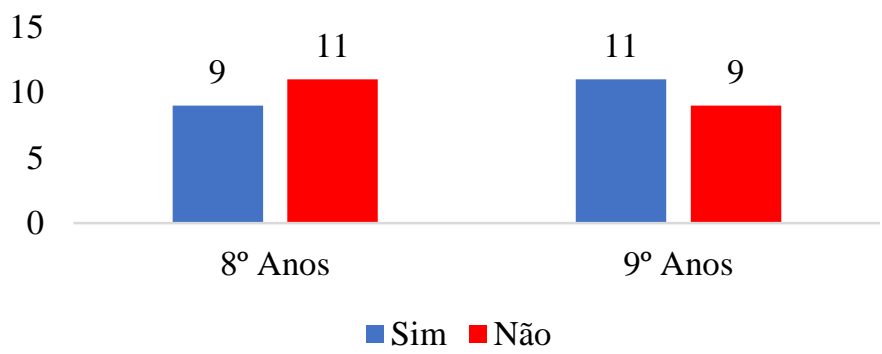

Perguntou-se também aos alunos, sobre às práticas sustentáveis direcionada a resíduos sólidos que eles adotam no cotidiano, sendo dispostas algumas alternativas, onde 50\% dos alunos participantes desta pesquisa apontaram evitar produtos descartáveis, o consumo exagerado, 17\% disseram que não adotam nenhuma prática em relação à questão e 15\% utilizam bolsas retornáveis (Figura 11).

Figura 11. Respostas dos alunos pesquisados sobre as práticas sustentáveis adotadas no seu dia-a-dia. 2019 


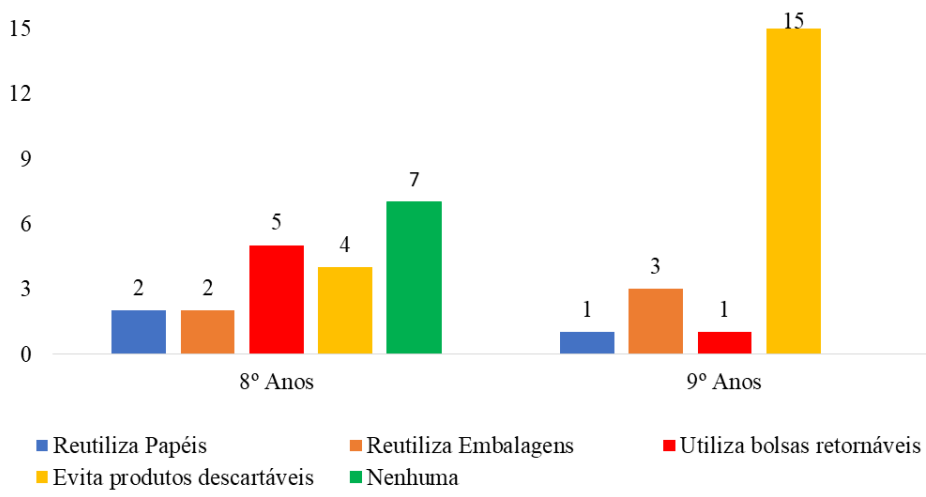

Em relação à decomposição dos resíduos sólidos no meio ambiente, a maioria dos alunos $(62,5 \%)$ afirmou conhecer o tempo de decomposição desses materiais no ambiente. Mesmo assim, muitos alunos pesquisados $(37,5 \%)$ demonstraram surpresa com relação ao tempo que os materiais demoram a se decompor no meio ambiente.

Dessa forma, esses resultados reafirmar a extrema necessidade de trabalhar e preparar o corpo docente e discente das escolas para se trabalhar na Educação Ambiental, cujo sentido principal é a formação de cidadãos conscientes para atuarem com sua cidadania de forma individual e/ou coletiva com relação à preservação do meio ambiente, na construção de valores, comportamentos, atitudes e hábitos buscando sempre uma sociedade sustentável. Percebe-se a carência desses tipos de abordagem na escola pesquisada, pois mesmo tendo sido uma abordagem incipiente com apenas uma sensibilização, os resultados se apresentaram como significativos e positivos.

Pode-se evidenciar que é fundamental e necessário um projeto de EA a ser desenvolvido na escola pesquisada a fim de se trabalhar uma plena e total sensibilização de toda a comunidade escolar para questões relativas aos resíduos sólidos, contemplando todos os aspectos relacionados à questão, incluindo o consumo exacerbado e puramente consumista com um descarte totalmente errado, deve-se buscar direcionar a implementação de gerenciamento adequado que priorize a não geração, a redução, a reutilização e reciclagem.

De acordo com Brasil (2001), só a implementação de um Programa de Gerenciamento de Resíduos Sólidos (PGRS) em consonância com um processo educativo é que poderá favorecer a formação de multiplicadores ambientais e sociais pautados em valores e significações para melhores tomadas de consciência, aliando teoria à prática, como pressupõem o Programa Parâmetros em Ação Meio Ambiente na Escola do Ministério da Educação MEC.

Tudo isto só poderá ser efetivado se os professores e alunos tiverem um maior e melhor acesso as informações de forma que possam compreender a temática ambiental de maneira profunda, refletindo sobre a importância no mundo e a relação estabelecida com ela. Para que isto possa ser efetivado é de extrema necessidade que toda a comunidade escolar se envolva efetivamente de maneira coletiva, se adequando sempre que necessário.

Portanto, diante dos resultados expostos anteriormente urge necessariamente a criação e implementação de “Oficinas de Educação Ambiental sobre os Resíduos Sólidos Escolares”, bem como de outros temas correlatos, 
destinados à formação continuada dos professores, como também, um "Plano de Gerenciamento de Resíduos

Sólidos - PGRS - Resíduos Sólidos Escolares", no intuito que essa experiência local possa transpassar os muros da escola e se estenda a todo o município.

\section{CONCLUSÃO}

$\mathrm{Na}$ escola pesquisada os setores de geração e descarte de resíduos principais foram a sala de coordenação e as salas de aula sendo o papel a maior quantidade, seguido do plástico; já no corredor da escola prevaleceu à produção de resíduos comuns e materiais como metal.

Os resíduos recicláveis gerados na escola são misturados e descartados como resíduo comum, porém, os mesmos, principalmente o papel e os plásticos poderiam ser reaproveitados e reciclados, mas a escola não possui um programa de separação de resíduos, isso talvez se justifique devido à inexistência de coleta seletiva municipal. Outro fato relevante observado foi o não aproveitamento do material orgânico, como restos de comida e as cascas de verduras que são também misturadas e descartadas como resíduos comuns, enquanto poderia ser reutilizada para compostagem ou para comida de animais como porcos e galinhas.

Analisado as respostas dos questionários observa-se que a maioria dos atores sociais pesquisados demonstra preocupação com as questões de cunho ambiental e reconhecem ser de sua responsabilidade o descarte adequado dos resíduos, sendo ponto positivo para promover ações que venha cada vez reforçar a consciência ambiental, como por exemplo, a escola desenvolver um trabalho permanente na área, que venha contribuir para melhorar as percepções já existentes e promover mudanças de comportamentos, valores, crenças e hábitos, facilitando o gerenciamento adequado dos resíduos que produzimos diariamente.

Verificou-se ainda que a comunidade não tem o hábito de colocar os resíduos nos coletores designado, mesmo com identificação, eles não respeitam, ou talvez não saibam diferenciar. As auxiliares de limpeza reclamam de os estudantes não contribuírem com a limpeza da escola, no entanto, mesmo sabendo do propósito de estarem na sala os dois coletores, retiravam, deixando apenas um. E ao final do dia, mesmo o que está separado nos coletores, é tudo misturado, inclusive o resíduo orgânico, com resíduos comuns como papel higiênico. Percebe-se assim que os professores não orientaram o alunado a observar a identificação nos coletores e que os resíduos espalhados na sala de aula, tornaram-se comum para eles. Percebeu-se que o pessoal do setor da secretaria se interessou em diferenciar resíduos recicláveis de resíduos comuns, mesmo não tendo conseguido de fato. A sala de coordenação caprichou tentando seguir à risca a separação de acordo com a designação dos coletores.

Algumas salas não têm cestos coletores e os que foram colocados, muitas vezes a identificação estava escondida, ato tanto feito pelos alunos como pelo pessoal da limpeza.

Para a comunidade escolar os hábitos de não importância ambiental quanto aos resíduos gerados e descartados tornaram-se normal. Diante disso, percebeu-se uma comunidade escolar quase que alheia aos problemas ambientais que ocorre ao seu redor, cada um fazendo o seu serviço nas pressas sem se importar se o modo como está fazendo vai ou não prejudicar o ambiente e consequentemente seus filhos, netos, bisnetos, necessitam com urgência de uma sensibilização para não dizer intervenção, que sirva para perceberem que do 
modo como estão agindo, misturando os resíduos, não orientando os alunos, sem zelo e compromisso ambiental não pode continuar.

\section{REFERÊNCIAS}

ARAÚJO, J.; MAGALHÃES, S. A educação do olhar: uma resposta a crise ambiental. Revista BIO\&THIKOS, v.4, n.3, p. 303-309, 2010.

BRASIL. Secretaria de Educação Fundamental. Parâmetros Curriculares Nacionais: Meio Ambiente e Saúde. Brasília: MEC/SEF, 1997, 128 p. Disponível em: <http://portal.mec.gov.br/seb/arquivos/pdf/livro091.pdf>. Acesso: 26 jul. 2019.

. Lei no 9795 de 27 de abril de 1999. Dispõe sobre a educação ambiental, institui a Política Nacional de Educação Ambiental e dá outras providências. Brasília, 27 de abril de 1999. Disponível em:< http://www.planalto.gov.br/ccivil_03/LEIS/L9795.htm>. Acesso: 7 ago. 2019.

Lei n. 12.305 de 02 agosto de 2010. Institui a Política Nacional de Resíduos Sólidos. Disponível em: <http://www.planalto.gov.br/ccivil_03/_ato2007-2010/2010/lei/112305.htm. Acesso em: 23 de jul. 2019.

Sistema Nacional de Informações sobre Saneamento (SNIS). Diagnóstico do Manejo de Resíduos

Sólidos Urbanos - 2013. Brasília: MCidades. SNSA, 2015. Disponível em: <http://www.snis.gov.br/diagnosticoresiduos-solidos/diagnostico-rs-2013 $\geq$. Acesso em: 7 ago. 2019.

BAETA, A. M. B. et al. Educação ambiental: repensando o espaço da cidadania. In: Educação ambiental: repensando o espaço da cidadania. 2002.

BARBOSA, R. P.; IBRAHIN, F. I. D. Resíduos Sólidos: impactos, manejo e gestão ambiental. São Paulo: Érica, 2014.

CARVALHO, I. C. M. Educação ambiental: a formação do sujeito ecológico. 6. ed. São Paulo: Cortez, 2012.

CONCEIÇÃO, C. B. Análise de resíduos sólidos em uma unidade escolar: proposição de plano de gerenciamento de resíduos sólidos. 2015. 94 f. Dissertação (Mestrado em Planejamento Ambiental) - Universidade Católica de Salvador, Salvador, 2015.

Conselho Nacional do Meio Ambiente - CONAMA. Resolução CONAMA no 275, de 25 de abril de 2001. Publicada no DOU no 117-E, de 19 de junho de 2001, s. 1, p. 80.

DE OLIVEIRA, A. C. P.; GIORDANO, E. O perfil dos diretores de escolas públicas no Brasil. Educação Online, v. 13, n. 27, p. 49-72, 2018.

DIAS, G. F. Educação Ambiental: princípios e práticas. 8. ed. São Paulo: Gaia, 2003.

FERNANDES, R. S.et al. Uso da percepção ambiental como instrumento de gestão em aplicações ligadas às áreas educacional, social e ambiental. In: II ENCONTRO DA ANPPAS, 2004, Indaiatuba. Associação Nacional de Pós-Graduação e Pesquisa em Ambiente e Sociedade, 2004. Disponível em:

<http://www.anppas.org.br/encontro_anual/encontro2/GT/GT10/roosevelt_fernandes.pdf>. Acesso: 4 ago. 2019.

FREITAS, N. T. A. Educação ambiental, consumo e resíduos sólidos no contexto da educação infantil: um diálogo necessário com os professores. 2018.

GADOTTI, M. A Carta da Terra na Educação. São Paulo: Editora e Livraria Instituto Paulo Freire, 2010, 103p.

GAZZINELLI, M. F. Representações do professor e implementação de currículo de educação ambiental. Cadernos de pesquisa, n. 115, p. 173-194, 2002.

JACOBI, P. R. Educação ambiental, cidadania e sustentabilidade. Cadernos de pesquisa, n. 118, p. 189-205, 2003.

LEFÈVRE, F.; LEFÈVRE, A. M. C. Depoimentos e discursos: uma proposta de análise em pesquisa social. In: Depoimentos e discursos: uma proposta de análise em pesquisa social. 2005. 
LOGAREZZI, A. Educação ambiental em resíduos: uma proposta de terminologia. In: CINQUETTI, H. C. S.; LOGAREZZI, A. (orgs). Consumo e resíduo: fundamentos para o trabalho educativo. São Carlos: EdUFSCar, p. 85-117, 2006.

LUIZ, L. C. et al. Agenda Ambiental na Administração Pública (A3P) e práticas de sustentabilidade: estudo aplicado em um instituto federal de educação, ciência e tecnologia. Administração pública e gestão social, v. 5 , n. 2, p. 54-62, 2013.

MESQUITA, E. G.; FIUZA, M. S. S.; SARTORI, H. J. F. Gerenciamento de resíduos sólidos: estudo de caso em campus universitário. Construindo, v. 3, n. 01, 2011.

ROCHA, C. M. C.; MOURA JUNIOR, A. M.; MAGALHÃES, K. M. Gestão de resíduos sólidos: percepção ambiental de universitários em uma instituição de ensino superior brasileira. Revista Eletrônica do Mestrado em Educação Ambiental. v. 29, jul a dez, p. 1-12, 2012.

SANTOS, I. R. et al. Educação ambiental e resíduos sólidos: percepção ambiental de alunos do ensino básico público em BELÉM/PA. In: Fórum Internacional de Resíduos Sólidos-Anais. 2018.

SILVA, G.P. A Educação Ambiental na Educação Infantil: tendências das produções acadêmicas de 2004-2014. 2017, 109 f. Dissertação (Mestrado em Educação Escolar) - Universidade Estadual Paulista, Faculdade de Ciências e Letras, Araraquara-SP, 2017.

SOUZA, M. R. Uma proposta de Educação Musical para a sensibilização ambiental. 2015, 116 f. Dissertação (Mestrado em Educação Escolar) - Faculdade de Ciências e Letras, Universidade Estadual Paulista, Araraquara-SP, 2015.

ZUBEN, F. V. Meio Ambiente, Cidadania e Educação. Departamento de Multimeios. Unicamp. Tetra Pak Ltda. 1998. 